\title{
Study of the Impact of sanitary decisions over water quality using Bayesian Belief Networks in Upper Pantanal Wetland Basin - Brazil
}

\author{
Estudo do Impacto das Decisões Sanitárias sobre a Qualidade da Água Utilizando Redes de \\ Crenças Bayesianas na Bacia do Pantanal do Alto Pantanal - Brasil \\ Estudio del Impacto de las decisiones sanitarias sobre la calidad del agua utilizando Redes de \\ Creencias Bayesianas en la Cuenca del Humedal del Alto Pantanal - Brasil
}

Received: 01/29/2022 | Reviewed: 02/03/2022 | Accept: 02/13/2022 | Published: 02/18/2022

\author{
Mayara Oliveira da Silva \\ ORCID: https://orcid.org/0000-0001-8139-8652 \\ Federal University of Rondonópolis, Brazil \\ E-mail: mayaraeaa@gmail.com \\ Domingos Sávio Barbosa \\ ORCID: https://orcid.org/0000-0001-6793-0956 \\ Federal University of Rondonópolis, Brazil \\ E-mail: domingosbar@gmail.com \\ Ricardo Alves de Olinda \\ ORCID: https://orcid.org/0000-0002-0509-8428 \\ State University of Paraíba, Brazil \\ E-mail: ricardoestat@yahoo.com.br \\ Camila Leonardo Mioto \\ ORCID: https://orcid.org/0000-0002-6951-9527 \\ Federal University of Rondonópolis, Brazil \\ E-mail: camila.mioto@ufr.edu.br
}

\begin{abstract}
Bayesian Belief Networks (BBN) modeling the water quality has become popular due to advances in computational techniques. For this instance, BBN is a useful tool to modeling the relationship between water quality data and population or urbanization parameters on a watershed scale. This method can combine primary water quality data and decision parameters and help scientists and decision-makers analyze several scenarios on a watershed, including the effect of scale. This paper aims to analyze and discuss the application of Bayesian Belief Network (BBN) on the relationship between watershed water quality and sanitary management indicators, studying a case on the Pantanal Wetland tributary watershed. Two scales BBN were constructed using ten years of water quality and sewage management datasets. Both BBNs were responsive and sensitive to water quality parameters. The Total Nitrogen and E. coli were de most essential parameters to simulate changes in water quality scenarios. The simulated scenarios showed structural limitations about the Pantanal Wetland Cities' sanitary system in the present study. We strongly recommend a review of the goals of sanitary structure and services and alert to the risk of a sanitary crisis in Pantanal Wetland.
\end{abstract}

Keywords: Sewage; Urbanization; River ecology.

\section{Resumo}

Bayesian Belief Networks (BBN) modelar a qualidade da água tornou-se popular devido aos avanços nas técnicas computacionais. Para este caso, o BBN é uma ferramenta útil para modelar a relação entre dados de qualidade da água e parâmetros populacionais ou de urbanização em uma escala de bacia hidrográfica. Esse método pode combinar dados primários de qualidade da água e parâmetros de decisão e ajudar cientistas e tomadores de decisão a analisar vários cenários em uma bacia hidrográfica, incluindo o efeito de escala. Este artigo tem como objetivo analisar e discutir a aplicação da Bayesian Belief Network (BBN) na relação entre a qualidade da água de uma bacia hidrográfica e os indicadores de gestão sanitária, estudando um caso na bacia afluente do Pantanal. Duas escalas BBN foram construídas usando dez anos de conjuntos de dados de qualidade da água e gestão de esgoto. Ambos os BBNs foram responsivos e sensíveis aos parâmetros de qualidade da água. O Nitrogênio Total e E. coli foram os parâmetros mais essenciais para simular mudanças nos cenários de qualidade da água. Os cenários simulados mostraram limitações estruturais sobre o sistema sanitário das Cidades do Pantanal do presente estudo. Recomendamos fortemente a revisão das metas de estrutura e serviços sanitários e alertamos para o risco de crise sanitária no Pantanal.

Palavras-chave: Esgoto; Urbanização; Ecologia do rio. 


\begin{abstract}
Resumen
Las redes de creencias bayesianas (BBN) que modelan la calidad del agua se han vuelto populares debido a los avances en las técnicas computacionales. Para este caso, BBN es una herramienta útil para modelar la relación entre los datos de calidad del agua y los parámetros de población o urbanización a escala de cuenca. Este método puede combinar datos primarios de calidad del agua y parámetros de decisión y ayudar a los científicos y a los encargados de tomar decisiones a analizar varios escenarios en una cuenca, incluido el efecto de escala. Este artículo tiene como objetivo analizar y discutir la aplicación de Bayesian Belief Network (BBN) sobre la relación entre la calidad del agua de la cuenca y los indicadores de gestión sanitaria, estudiando un caso en la cuenca tributaria del Pantanal. Se construyeron dos BBN a escala utilizando diez años de conjuntos de datos de gestión de aguas residuales y calidad del agua. Ambos BBN respondieron y fueron sensibles a los parámetros de calidad del agua. El Nitrógeno Total y E. coli fueron los parámetros más esenciales para simular cambios en los escenarios de calidad del agua. Los escenarios simulados mostraron limitaciones estructurales sobre el sistema sanitario de las Ciudades de Humedales del Pantanal en el presente estudio. Recomendamos encarecidamente una revisión de las metas de estructura y servicios sanitarios y alertar sobre el riesgo de una crisis sanitaria en el Pantanal.
\end{abstract}

Palabras clave: Aguas residuales; Urbanización; Ecología fluvial.

\title{
1. Introduction
}

Bayesian Belief Networks (BBN) modeling the water quality has become popular due to advances in computational techniques. Several studies demonstrated the importance of developing theses methods with or without another statistical approach (Ancione et. al., 2020; Farooqi et al., 2020; Kang et al., 2020; Mayfield et al., 2019; Panidhapu et al., 2019; Avila et al., 2018).

As another emergent country in the global south, Brazil has many challenges about sanitary and water quality issues. As discussed by Borrero-Ramírez and Mosquera-Becerra, (2020) the current sanitary crisis on the global south is understood in the context of health systems that have experienced significant transformations in the last decades due to the market-driven actors to influence health policy decisions. A very complex scenario needs to be solved, and a decision can consider several physical, geographical, and policy variables.

Differentially of well-developed nations of the world, scientific decision-based tools are needed urgently in these areas. For this instance, $\mathrm{BN}$ is a useful tool to modeling the relationship between water quality data and population or urbanization parameters on a watershed scale (Fasaee et al., 2021; Salman et al., 2021; Forio et al., 2015). This method can combine primary water quality data and decision parameters and help scientists and decision-makers analyze several scenarios on a watershed, including the effect of scale.

Look at closing in Brazil, specifically in Pantanal Wetland, the world's largest wetland; one of the many environmental problems is sewage treatment. Recently, the wildfires call the attention of the world due to severity of the wildflife and extension of the burned area (Pivello et al., 2021). However, we attempt for another emergent disaster: the sanitary crisis. These can occur due to the disruption between policy decisions and scientific indicators, such as water quality index (WQI).

A critical issue to modeling the relationship between the population and the urbanization effect over watershed water quality. In these situations, the decision-makers need a tool to compare different population levels and their impact on water quality goals.

This scale effect is particularly significant when considering the practice effect of decision-makers over watershed management. In practical aspects, managers can be using the specific concept of jurisdiction to define the geographic limits of their actions. Several approaches used the hierarchy effect in space and time to understand these (Sha et al., 2014; Zhang et al., 2018; Liu et al., 2019). Accordilig Wan et al. (2014) process-based watershed pollution models have proved useful to simulate complex processes, for example, a Bayesian hierarchical model that investigated the effects of air pollution on health over time. 
This paper aims to analyze and discuss the application of Bayesian Belief Network (BBN) on the relationship between watershed water quality and sanitary management indicators, studying a case on the Pantanal Wetland tributary watershed.

\section{Methodology}

\subsection{Study area characterization}

The study was carried out in the Vermelho River basin $\left(15^{\circ} 30^{\prime} / 17^{\circ} 15^{\prime} \mathrm{S}\right.$ and $\left.53^{\circ} 45^{\prime} / 55^{\circ} 00^{\prime} \mathrm{W}\right)$, are located in the southeastern region of the State of Mato Grosso, Brazi (Figure 01). The basin occupies an area of approximately 150,802 ha. (Souza \& Loverde-Oliveira, 2014) and is an essential contributor to the Pantanal Wetlands. The main uses and occupations are cattle raising, followed by soybean, corn, and cotton crops, in addition to urbanized areas. The city of Rondonópolis. It has the largest population in the basin with 232,491 inhabitants, with a demographic density of $47.00 \mathrm{inhab} . / \mathrm{km}^{2}$.

The Rio Vermelho Basin has high ecological complexity and needs priority attention. Included in the area are three indigenous communities (Tadarimana, Jarudore, and Tereza Cristina), with the Tadarimana indigenous land covering about 9,785 ha, equivalent to the current urban area of the Municipality of Rondonópolis. Two large state conservation units are also located (Dom Osório Stoffel State Park, 6,421.69 ha and RPPN João Basso 3,624.57 ha). Two hydropower plants (Ponte de Pedra, 176 MW and Rondonópolis 26.60 MW) also share in the territory of the basin.

Figure 1: Vermelho River Basin and Pantanal Wetland.

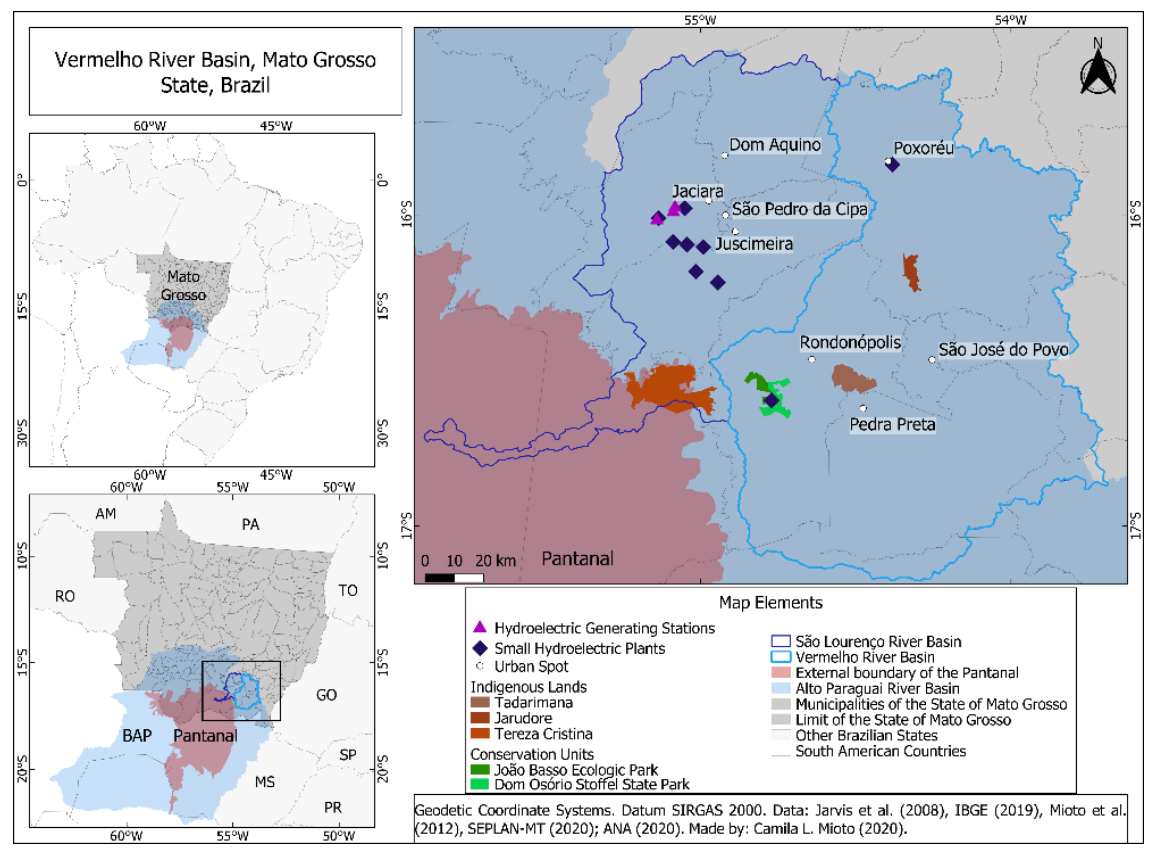

Source: Elaborated by the authors (2022).

\subsection{Water quality database}

The Vermelho River Water quality Dataset was obtained from governmental water quality databases (Secretaria Estadual de Meio Ambiente - SEMA MT) and the official sanitary management indicators by the national database of sanitation (National System of Sanitation Information -SNIS). Complementary hydraulic data (river discharge) was obtained by the National Water Authority (Agencia Nacional de Águas - ANA). The period selected to study was between 2006 and 2017 due to previous database consistency study (Garcia, et al. 2020). A total of 1778 points of dataset over 14 variables were select to study. 
The original dataset variables were paired by supervisoned and manual selection, when inconsistent and no-data cases were excluded from making the cases. Nodes named each select variable, and thus, the Conditional Probability Table (CPT) was created. To evaluate the watershed's scale effect in this study, we created two CPTs from the total basin dataset (BBNw) and only the Rondonopolis city influence area (BBNc).

\subsection{Conceptual model and basic network algorithm}

The essential criteria to define the structure of the network are described in Ramin et al. (2012), Wijesiri et al. (2018), and Panidhapu et al. (2020). In synthesis, we used a supervised conceptual model to design the basic algorithm using in the construction of BNN (Figure 2). The model was constructed based on previous studies (Silva, et al, 2020) when was demonstrated the effect of seasonality (rain and dry seasons) on the water quality variables. The effect of urbanization and sanitation systems at the river basin scale on the water quality was discussed in another previous study (Garcia, et al. 2020). The analysis considered the multivariate statistical correlation between the water quality variables on time and space scales. In the synthesis, the major water quality driving forces at Rio Vermelho basis are the seasonality that changes turbidity, suspended solids, and total coliforms. Urbanization and Population growth change majority Nitrogen, Phosphorus, C.O.D. Colour, and E. coli. Finally, all these variables change de W.Q.I. index.

Figure 2: Conceptual model used as a basic algorithm to design the Bayesian Belief Network (BBN) in this study, based on limnological and ecological concepts. In the left the general model, and in the right the river water quality sub-model.

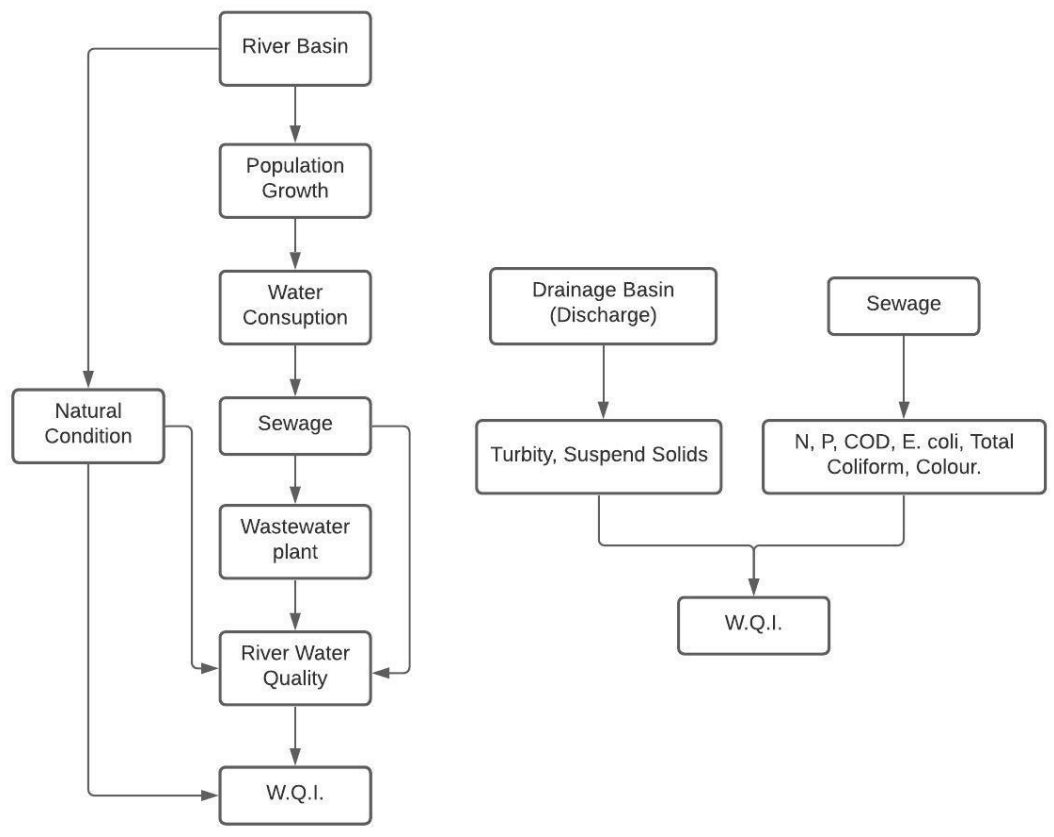

Source: Elaborated by the authors (2022).

\subsection{BBN model construction and validation}

A typical mathematical representation of a Bayesian Belief Network is $(\mathrm{BBN})$, can be formulated by $\mathrm{BBN}=(G, \Theta)$, where $B B N G$ is a directed acyclic graph (DAG), in which its nodes $X_{1}, X_{2}, \ldots X n$, represents random variables (nodes) and their links represent direct dependencies between these variables, and $\Theta$ represents the set of BBN parameters, $P\left(X_{i} \mid A_{i}\right)(i=1$, 
$2, \ldots, n)$ for each $X i$ conditioned on the set of $A i$ (parents of $X i$ in $G$ ). The conditional dependence and $P(X)$ described by Eqquation (1):

$$
P(X)=\prod_{i=1}^{n} P\left(X_{i} \mid A_{i}\right)
$$

The goal of these modeling is to create scenarios for simulation when the decision-makers evaluate the impact of the sewage system and urbanization on the water quality. The Bayesian Belief Network (BNN) was constructed using the primary data along 10 years of a dataset. We construct two CPT based on historical datasets to evaluate the basin-scale effect: BBN to whole watershed (BBNw) and BBN to greatest city basin (Rondonópolis City) called BBNc.

In both cases, two entrance variables (node) are the Population With Sanitary System (PWS), which means the absolute value of the people that access adequate wastewater disposal and, Water Consumption (WCS), means the total volume $\left(\mathrm{m}^{3}\right)$ of water consumption by the population in the study. These entrances nodes were considered the best to the goals because are clear to decision-makers and other stakeholders create executive action plans.

To construct the two BNNs for testing the basin-scale effect, the whole watershed (BBNw), and the greatest city basin (Rondonópolis City) called BBNc, we adjusted the cases and the CPT to the nodes PWS, WCS, and VST. In both cases, we use the validation criteria described below. The other nodes of the river water quality are the same in both scenarios.

The final node is the Water Quality Index (WQI), which means the goal of water quality management. We used the software NETICA (Norsis, version 6.07) to construct and-run the BNN. The primary data was used to construct the Conditional Probabilities Table (CPT) and the discretization criteria into three levels, was conducted by expert analysis. All nodes and their value characteristics are described in Table 1.

Table 1: Nodes of the BNNs in this study. Range values are the discretization criteria.

\begin{tabular}{|c|c|c|c|c|c|c|c|}
\hline Variable & $\begin{array}{l}\text { Code } \\
\text { name }\end{array}$ & Unity & $\begin{array}{c}\text { Mean ( } \pm \text { S.D. }) \\
\text { database BBNc }\end{array}$ & $\begin{array}{c}\text { Mean ( } \pm \text { S.D. }) \\
\text { database BBNw }\end{array}$ & $\begin{array}{c}\text { BBNc Range } \\
\text { Values }\end{array}$ & $\begin{array}{c}\text { BBNw Range } \\
\text { Values }\end{array}$ & Discretization \\
\hline $\begin{array}{l}\text { Population With } \\
\text { Sanitary System }\end{array}$ & PWS & $\begin{array}{c}\text { Number of } \\
\text { people }\end{array}$ & \multirow{3}{*}{$\begin{array}{c}68457,24 \\
\pm \\
18149,08\end{array}$} & \multirow{3}{*}{$\begin{array}{c}86174,67 \\
\pm \\
43301,07\end{array}$} & $\begin{array}{c}52.664 \text { to } \\
106.214\end{array}$ & $\begin{array}{c}55.000 \text { to } \\
110.249\end{array}$ & Low \\
\hline $\begin{array}{l}\text { Population With } \\
\text { Sanitary System }\end{array}$ & PWS & $\begin{array}{c}\text { Number of } \\
\text { people }\end{array}$ & & & $\begin{array}{l}106.214 \text { to } \\
159.765\end{array}$ & $\begin{array}{c}110.249 \text { to } \\
165499\end{array}$ & Medium \\
\hline $\begin{array}{l}\text { Population With } \\
\text { Sanitary System }\end{array}$ & PWS & $\begin{array}{c}\text { Number of } \\
\text { people }\end{array}$ & & & $\begin{array}{l}159.765 \text { to } \\
213.316\end{array}$ & $\begin{array}{l}165.499 \text { to } \\
220.749\end{array}$ & Height \\
\hline Water Consumption & WCS & $\mathrm{m}^{3}$ & \multirow{3}{*}{$\begin{array}{c}10907,5 \\
\pm \\
2184,41\end{array}$} & \multirow{3}{*}{$\begin{array}{c}12701,51 \\
\pm \\
1986,31\end{array}$} & $\begin{array}{c}7.413,6 \text { to } \\
9.846,86\end{array}$ & $\begin{array}{c}8.773,82 \text { to } \\
10.973,64\end{array}$ & Low \\
\hline Water Consumption & WCS & $\mathrm{m}^{3}$ & & & $\begin{array}{c}9.846,86 \text { to } \\
12.280,13\end{array}$ & $\begin{array}{c}10.973,64 \text { to } \\
13.173,46\end{array}$ & Medium \\
\hline Water Consumption & WCS & $\mathrm{m}^{3}$ & & & $\begin{array}{c}12.280,13 \text { to } \\
14.713,4\end{array}$ & $\begin{array}{c}13173,46 \text { to } \\
15.373,28\end{array}$ & Height \\
\hline
\end{tabular}




\begin{tabular}{|c|c|c|c|c|c|c|c|}
\hline $\begin{array}{c}\text { Volume Sewage } \\
\text { Treated }\end{array}$ & VST & $\mathrm{m}^{3}$ & \multirow{3}{*}{$\begin{array}{c}4137,05 \\
\pm \\
933,55\end{array}$} & \multirow{3}{*}{$\begin{array}{c}4627,04 \\
\pm \\
1482,02\end{array}$} & $\begin{array}{l}2.977 \text { to } \\
5.125,66\end{array}$ & $\begin{array}{l}3.029 \text { to } \\
5.195,32\end{array}$ & Low \\
\hline $\begin{array}{c}\text { Volume Sewage } \\
\text { Treated }\end{array}$ & VST & $\mathrm{m}^{3}$ & & & $\begin{array}{l}5.125,66 \text { to } \\
7.274,32\end{array}$ & $\begin{array}{l}5.195,32 \text { to } \\
7.361,64\end{array}$ & Medium \\
\hline $\begin{array}{c}\text { Volume Sewage } \\
\text { Treated }\end{array}$ & VST & $\mathrm{m}^{3}$ & & & $\begin{array}{l}7.274,32 \text { to } \\
9.423\end{array}$ & $\begin{array}{c}7.361,64 \text { to } \\
9.527,97\end{array}$ & Height \\
\hline $\begin{array}{c}\text { Quarterly Average } \\
\text { Flow }\end{array}$ & QAF & $\mathrm{m}^{3} / \mathrm{s}$ & 144,17 & 96,01 & $\begin{array}{c}56.86 \text { to } \\
144,23\end{array}$ & 6 to 115 & Low \\
\hline $\begin{array}{c}\text { Quarterly Average } \\
\text { Flow }\end{array}$ & QAF & $\mathrm{m}^{3} / \mathrm{s}$ & 86,38 & 83,01 & $\begin{array}{c}144,23 \text { to } \\
239,16\end{array}$ & 115 to 124 & Medium \\
\hline $\begin{array}{c}\text { Quarterly Average } \\
\text { Flow }\end{array}$ & QAF & $\mathrm{m}^{3} / \mathrm{s}$ & & & $\begin{array}{l}239,16 \text { to } \\
334,097\end{array}$ & 224 to 335 & Height \\
\hline Color & $\mathrm{COL}$ & UC & 67,14 & 62,83 & 6 to 136 & 2 to 133 & Low \\
\hline Color & $\mathrm{COL}$ & UC & 59,44 & 56,2 & 136 to 266 & 133 to 264 & Medium \\
\hline Color & $\mathrm{COL}$ & UC & & & 266 to 396 & 264 to 397 & Height \\
\hline $\begin{array}{c}\text { Biochemical Oxygen } \\
\text { Demand }\end{array}$ & BOD & mg/L.O2 & 21,52 & 24,47 & 6 to 44 & 6 to 44 & Low \\
\hline $\begin{array}{l}\text { Biochemical Oxygen } \\
\text { Demand }\end{array}$ & BOD & mg/L.O2 & 10,79 & 15,68 & 44 to 82 & 44 to 82 & Medium \\
\hline $\begin{array}{c}\text { Biochemical Oxygen } \\
\text { Demand }\end{array}$ & BOD & mg/L.O2 & & & 82 to 120 & 82 to 120 & Height \\
\hline Total Nitrogen & TNI & mg/L.N & 1,14 & 1,28 & 0,05 to 1,46 & 0,05 to 1,9 & Low \\
\hline Total Nitrogen & TNI & mg/L.N & 1,13 & 1,23 & 1,46 to 2,88 & 1,9 to 3,8 & Medium \\
\hline Total Nitrogen & TNI & mg/L.N & & & 2,88 to 4,3 & 3,58 to 5,6 & Height \\
\hline Total Coliforms & TCO & $\mathrm{NMP} / 100 \mathrm{ml}$ & $\begin{array}{c}20103,76 \\
\pm\end{array}$ & $\begin{array}{c}18708,29 \\
\pm\end{array}$ & $\begin{array}{l}1.986 \text { to } \\
9.389,33\end{array}$ & 435 to 8355 & Low \\
\hline Total Coliforms & $\mathrm{TCO}$ & $\mathrm{NMP} / 100 \mathrm{ml}$ & 7163,67 & 7817,89 & $\begin{array}{c}9.389,33 \text { to } \\
16.792,66\end{array}$ & $\begin{array}{l}8.355 \text { to } \\
16.275\end{array}$ & Medium \\
\hline Total Coliforms & $\mathrm{TCO}$ & $\mathrm{NMP} / 100 \mathrm{ml}$ & & & $\begin{array}{c}16.792,66 \text { to } \\
24.196\end{array}$ & $\begin{array}{c}16.275 \text { to } \\
24.196\end{array}$ & Height \\
\hline $\begin{array}{l}\text { Non-filterable } \\
\text { Residue }\end{array}$ & NFR & $\mathrm{mg} / \mathrm{L}$ & 106,93 & 88,77 & 2 to 446 & 1 to 445 & Low \\
\hline $\begin{array}{l}\text { Non-filterable } \\
\text { Residue }\end{array}$ & NFR & $\mathrm{mg} / \mathrm{L}$ & 213,55 & 176,03 & 446 to 890 & 445 to 889 & Medium \\
\hline
\end{tabular}




\begin{tabular}{|c|c|c|c|c|c|c|c|}
\hline $\begin{array}{l}\text { Non-filterable } \\
\text { Residue }\end{array}$ & NFR & $\mathrm{mg} / \mathrm{L}$ & & & 890 to 1.334 & 889 to 1.334 & Height \\
\hline Escherichia coli & ESC & $\mathrm{NMP} / 100 \mathrm{ml}$ & \multirow{3}{*}{$\begin{array}{c}9549,17 \\
\pm \\
9648,21\end{array}$} & \multirow{3}{*}{$\begin{array}{c}6764,29 \\
\pm \\
8387,85\end{array}$} & $\begin{array}{c}201 \text { to } \\
8.202,66\end{array}$ & 20 to 8078 & Low \\
\hline Escherichia coli & ESC & $\mathrm{NMP} / 100 \mathrm{ml}$ & & & $\begin{array}{c}8.202,66 \text { to } \\
16.199,33\end{array}$ & 8.078 to 16137 & Medium \\
\hline Escherichia coli & ESC & $\mathrm{NMP} / 100 \mathrm{ml}$ & & & $\begin{array}{c}16.199,33 \text { to } \\
24.196\end{array}$ & $\begin{array}{c}16.137 \text { to } \\
24.196\end{array}$ & Height \\
\hline Total Phosphorus & TPH & $\mathrm{mg} \mathrm{P} / \mathrm{L}$ & \multirow{3}{*}{$\begin{array}{c}0,21 \\
\pm \\
0,16\end{array}$} & \multirow{3}{*}{$\begin{array}{c}0,27 \\
\pm \\
0,38\end{array}$} & 0,05 to 0,61 & 0,02 to 0,82 & Low \\
\hline Total Phosphorus & $\mathrm{TPH}$ & $\mathrm{mg} \mathrm{P} / \mathrm{L}$ & & & 0,61 to 1,17 & 0,82 to 1,63 & Medium \\
\hline Total Phosphorus & TPH & $\mathrm{mg} P / \mathrm{L}$ & & & 1,17 to 1,74 & 1,63 to 2,44 & Height \\
\hline Turbidity & TUR & NTU & \multirow{3}{*}{$\begin{array}{c}209,64 \\
\pm \\
657,53\end{array}$} & \multirow{3}{*}{$\begin{array}{c}171,12 \\
\pm \\
495,58\end{array}$} & 1,5 to 1.251 & 0,07 to 1250 & Low \\
\hline Turbidity & TUR & NTU & & & $\begin{array}{l}1.251 \text { to } \\
2.501,16\end{array}$ & 1.250 to 2.500 & Medium \\
\hline Turbidity & TUR & NTU & & & $\begin{array}{c}2.501,16 \text { to } \\
3.751\end{array}$ & 2.500 to 3.752 & Height \\
\hline Total Residue & TRE & $\mathrm{mg} / \mathrm{L}$ & \multirow{3}{*}{$\begin{array}{c}210,52 \\
\pm \\
237,6\end{array}$} & \multirow{3}{*}{$\begin{array}{c}213 \\
\pm \\
234,3\end{array}$} & 20 to 513 & 20 to 513 & Low \\
\hline Total Residue & TRE & $\mathrm{mg} / \mathrm{L}$ & & & 513 to 1.006 & 513 to 1.006 & Medium \\
\hline Total Residue & TRE & $\mathrm{mg} / \mathrm{L}$ & & & 1.006 to 1.499 & 1.006 to 1.500 & Height \\
\hline Water Quality Index & WQI & & \multirow{3}{*}{$\begin{array}{c}55,76 \\
\pm \\
9,35\end{array}$} & \multirow{3}{*}{$\begin{array}{c}57,74 \\
\pm \\
10,86\end{array}$} & 0 to 50 & 0 to 50 & Bad \\
\hline Water Quality Index & WQI & & & & 50 to 70 & 50 to 70 & Medium \\
\hline Water Quality Index & WQI & & & & 70 to 100 & 70 to 100 & Good \\
\hline
\end{tabular}

Source: Elaborated by the authors (2022).

The validation of BNN modeling was conducted accordingly Marcot et al. (2006). In synthesis, we create de CPT for nodes and discretize using expertise-based criteria. All the nodes appear with their states (height, medium, or low) based on the maximum, medium, and minimum value. Next, using NETICA®, the directed acyclic graph (DAG) was created hen arcs connect the nodes according to the basic conceptual model described in Figure 2. To the network learning, we use the expectation-maximization (EM) algorithm. The WQI node was used as a reference to test with cases, evaluating the prediction accuracy of BNN model by analysis of confusion matrix comparing predicted with actual outcomes. Additionally, the Error 
rate (\%), Logarithmic loss, Quadratic loss and, Spherical payoff parameters were used as model quality criteria. Finally, by specialist judgment, the DAG was adjusted by ordering the arcs and nodes for the maximum fit of network parameters described above. The final BBN is shown in Figure 3.

Figure 3: The BBN developed in this study. The structure were used in both BBNw and BBNc.

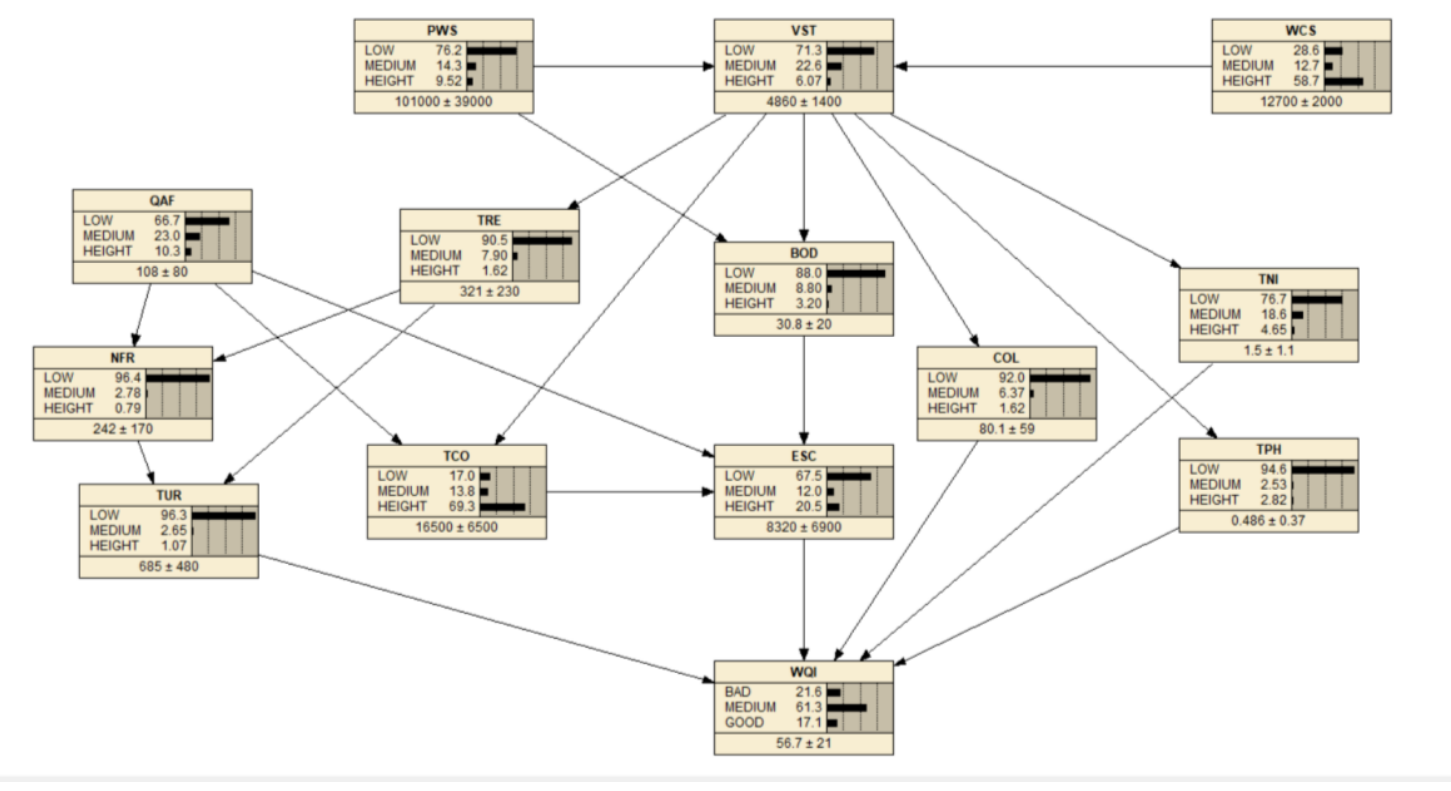

Source: Elaborated by the authors (2022).

\section{Results and Discussion}

\subsection{BBNs performance and validation}

We discuss the results in two ways: the performance of two BNNs and the potential of clearance water quality and sewage management scenarios. As shown in Table 02, the results of the validation parameters for two BNNs can be viewed as a scalar effect. Adjusting the cases from BBNw (126 cases) to BBNc (64 cases) was reduced due to some data that don't cover the watershed area under the influence for Rondonópolis city.

The $3 \times 3$ confusion matrix (Table 02) shown the accuracy of both BBN. The overall error rate can be considered acceptable for both BBNs (26,98\% and 13,79 \%, from BBNw and BBNc, respectively). In the BBNw the Medium state can't predict correctly at $16,6 \%$ level. In the BNNc the most important error is Bad state at $12,5 \%$. In both cases, as expected, the good state doesn't show results to predicted, due to the river WQI don't have sufficiently good states data to machine learning. The WQI of the Vermelho river doesn't have good quality state, as demonstrated by database analysis.

As discussed by Marcot et al. (2006), the confusion matrix is shown how the number of known cases that were correctly classified. This approach is a parameter of the quality of the capture model and can be used to interpret the simulations. In this case, the average of correct classifications of both models is around 79,5\%.

This result can be to infer too the effect of the watershed scale on the model accuracy. The BNNc is more accurate due to BNNw, probably due to the effect of Rondonópolis city on the water quality is more pronounced when compared with the whole basin. In other words, the loss of water quality (WQI) can be explained by changes on population parameters (PWS, WC, and VST). In BBNw we consider the particular effect to waste disposal on the loss of accuracy of the model. In Brazilian small cities, as a Vermelho river basin, is common the urban wastewater disposal occurs by septic tanks or open defection, and don't result in a significative change on the surface waters. 
Table 2: Confusion matrix, Error rate, Logarithmic loss, Quadratic loss, and Spherical payoff to BBNw and BBNc to evaluate the accuracy of the models.

\begin{tabular}{|c|c|c|c|c|c|c|}
\hline \multicolumn{7}{|c|}{ Confusion Matrix from WQI } \\
\hline \multicolumn{3}{|c|}{ Predicted BBNw (126 cases) } & \multicolumn{3}{|c|}{ Predicted BBNc (64 cases) } & \multirow{2}{*}{ Actual } \\
\hline $\mathrm{Bad}$ & Medium & Good & $\mathrm{Bad}$ & Medium & Good & \\
\hline 22 & 10 & 0 & 8 & 1 & 0 & $\mathrm{Bad}$ \\
\hline 3 & 70 & 0 & 2 & 17 & 0 & Medium \\
\hline 0 & 21 & 0 & 0 & 1 & 0 & Good \\
\hline \multicolumn{3}{|c|}{ Error rate $=26.98 \%$} & \multicolumn{3}{|c|}{ Error rate $=13.79 \%$} & \\
\hline \multicolumn{6}{|c|}{ Scoring Rule Results: } & \\
\hline \multicolumn{3}{|c|}{ Logarithmic loss $=0.5778$} & \multicolumn{3}{|c|}{ Logarithmic loss $=0.3035$} & \\
\hline \multicolumn{3}{|c|}{ Quadratic loss $=0.3718$} & \multicolumn{3}{|c|}{ Quadratic loss $=0.1878$} & \\
\hline \multicolumn{3}{|c|}{ Spherical payoff $=0.7869$} & \multicolumn{3}{|c|}{ Spherical payoff $=0.8963$} & \\
\hline
\end{tabular}

Source: Elaborated by the authors (2022).

The sensitivity of findings to target node WQI in table 03, reported the variance reduction of WQI nodes (as variables on the dataset) due to a finding another single node. The top five nodes of both BBN represents the same variables, including the importance ordering of these. These result can be interpreted as both BBN scale approaches can be suitable for the conceptual model. At watershed-scale analysis $(\mathrm{BBNw})$ E. coli is more important to WQI variance reduction while compared when city-scale $(\mathrm{BBNc})$. Another hand, the total nitrogen changes impact the WQI on the watershed scale (BBNw).

Table 3: Sensitivity of findings from capture the WQI of Vermelho River basin in two watershed scales. (BBNw and BBNc).

\begin{tabular}{lcc}
\hline \multicolumn{3}{c}{ BBNw } \\
\hline Node & Variance Reduction & Percent \\
TNI & 33.69 & 7.69 \\
ESC & 23.08 & 5.27 \\
COL & 19.45 & 4.44 \\
TCO & 2.862 & 0.653 \\
BOD & 2.087 & 0.476 \\
\hline \multicolumn{3}{|}{ BBNc } \\
\hline Node & Variance Reduction \\
TNI & 79.94 & Percent \\
ESC & 17.79 & 16.3 \\
COL & 4.862 & 3.64 \\
TPH & 4.367 & 0.994 \\
BOD & 2.344 & 0.893 \\
& Source: Elaborated by the authors $(2022)$ & 0.479 \\
\hline
\end{tabular}

Source: Elaborated by the authors (2022).

\subsection{Scenario simulations}

For water quality simulations, three major scenarios were selected into entrance conditions: Sewage Services, Sewage Structure, and Water consumption om BBNw. The beliefs of WQI index changes were analyzed. Other scenarios were conducted (not shown here). The results are shown in Table 04. In synthesis, high sanitary services and structure reduce beliefs of states Bad and Medium WQI and increase the Good ones. Another hand, high water consumption increases the beliefs of Bad and Medium states of WQI.

These results can be interpreted as a result of the impact of management decisions on water quality. In Brazil the sewage structure is different by their services ones. The structure is a physical extension of the sewage network, and the 
services are the number of people who use these services. Another result is the changes of WQI is a majority over Bad and Medium states. As described in 2.1 section, the Good state doesn't frequently appear in the data set, and the network learing captures these.

Finally, Best and Worst Scenarios was created combining the conditions of entrances nodes: Best scenario: High Structure and sewage services with Low Water Consumption. Worst Scenario, Low Structure and Sewage Services with High Water consumption. The results show in Table 04 reveals the same tendency as other scenarios, when the best management practices reduce the beliefs over Bad and Medium states of WQI. However, don't increase the Good state of WQI significantly.

Table 4: Beliefs of WQI changes by selected scenarios.

\begin{tabular}{lcc}
\hline \multicolumn{1}{c}{ WQI index } & \multicolumn{2}{c}{ WQI Scenarios - Beliefs } \\
\hline Bad & Low Sewage Services & Hight Sewage Services \\
Medium & 0,21 & 0,24 \\
Good & 0,62 & 0,58 \\
& 0,17 & 0,18 \\
Bad & & Hight Sewage Structure \\
Medium & 0,20 & 0,24 \\
Good & 0,62 & 0,56 \\
& 0,18 & 0,19 \\
Bad & & Sewage Structure \\
Medium & Low Water Consumption & 0,24 \\
Good & 0,21 & 0,60 \\
& 0,61 & 0,17 \\
Bad & 0,17 & Worst Scenario \\
Medium & Best Scenario & 0,20 \\
Good & 0,24 & 0,62 \\
\hline
\end{tabular}

Source: Elaborated by the authors (2022).

\section{Conclusion}

Both BBNs were responsive and sensitive to water quality parameters. In two analyzed scales (whole watershed and city influence) Total Nitrogen and E. coli were de most essential parameters to simulate changes in water quality scenarios.

The simulated scenarios showed a structural limitations about the Pantanal Wetland Cities' sanitary system in the present study. Probably, even in the best scenario, the beliefs don't indicate a Good state of WQI of Vermelho River due to limitations of dataset or the insufficient sanitary system structure. We strongly recommend a review of the goals of sanitary structure and services and alert to the risk of a sanitary crisis in Pantanal Wetland.

As a suggestion for future research, it is the application of the methodology in other river basins, with some adaptations of the intrinsic variables. This method is scalable to consider large geographical areas because the same decisions can cover several river basins. However, the gap effect of decisions will need to be considered an essential factor in model adjustments. Some environmental effects do not model by decision-making presupposes because they are not a result of decisions but by an absence of initiatives. This paradox addresses a future scientific discussion. 


\section{References}

Ancione, G., Bragatto, P., \& Milazzo, M. F. (2020). A Bayesian network-based approach for the assessment and management of ageing in major hazard establishments. Journal of Loss Prevention in the Process Industries, 104080. 10.1016/j.jlp.2020.104080

Avila, R., Horn, B., Moriarty, E., Hodson, R., \& Moltchanova, E. (2018). Evaluating statistical model performance in water quality prediction. Journal of Environmental Management, 206, 910-919. 10.1016/j.jenvman.2017.11.049

Borrero-Ramírez, Y., \& Mosquera-Becerra, J. (2020). Emancipation versus normality in the Global South. International Journal of Public Health. $10.1007 / \mathrm{s} 00038-020-01466-4$

Farooqi, Z. U. R., Sabir, M., Latif, J., Aslam, Z., Ahmad, H. R., Ahmad, I., Imran, M., \& Ilić, P. (2019). Assessment of noise pollution and its effects on human health in industrial hub of Pakistan. Environmental Science and Pollution Research, 27(3), 2819-2828. 10.1007/s11356-019-07105-7

Fasaee, M. A. K., Berglund, E., Pieper, K. J., Ling, E., Benham, B., \& Edwards, M. (2021). Developing a framework for classifying water lead levels at private drinking water systems: A Bayesian Belief Network approach. Water Research, 189, 116641. 10.1016/j.watres.2020.116641

Forio, M. A. E., Landuyt, D., Bennetsen, E., Lock, K., Nguyen, T. H. T., Ambarita, M. N. D., \& Goethals, P. L. M. (2015). Bayesian belief network models to analyse and predict ecological water quality in rivers. Ecological Modelling, 312, 222-238. 10.1016/j.ecolmodel.2015.05.0

Garcia, B. H. Y., Olinda, R. A., Barbosa, D. S., \& Mioto, C. L. (2020). Substantive audit testing of sewer systems using Brazilian open database: stat methods for compliance screening. Revista Ibero Americana de Ciências Ambientais, 11(6),716-724. 10.6008/CBPC2179-6858.2020.006.0057

Kang, G., Qiu, Y., Wang, Q., Qi, Z., Sun, Y., \& Wang, Y. (2020). Exploration of the critical factors influencing the water quality in two contrasting climatic regions. Environmental Science and Pollution Research. 10.1007/s11356-020-07786-5

Liu, J., Liu, R., Zhang, Z., Cai, Y., \& Zhang, L. (2019). A Bayesian Network-based risk dynamic simulation model for accidental water pollution discharge of mine tailings ponds at watershed-scale. Journal of Environmental Management, 246, 821-831. 10.1016/j.jenvman.2019.06.060

Mayfield, H. J., Bertone, E., Smith, C., \& Sahin, O. (2019). Use of a structure aware discretisation algorithm for Bayesian networks applied to water quality predictions. Mathematics and Computers in Simulation. 10.1016/j.matcom.2019.07.005

Panidhapu, A., Li, Z., Aliashrafi, A., \& Peleato, N. M. (2019). Integration of weather conditions for predicting microbial water quality using Bayesian Belief Networks. Water Research, 115349. 10.1016/j.watres.2019.115349

Pivello, V. R., Vieira, I., Christianini, A. V., Ribeiro, D. B., da Silva Menezes, L., Berlinck, C. N., Melo, F. P. L., Marengo, J. A., Tornquist, C. G., Tomas W. M., \& Overbeck, G. E. (2021). Understanding Brazil's catastrophic fires: Causes, consequences and policy needed to prevent future tragedies. Perspectives in Ecology and Conservation, 19(3), 233-255. 10.1016/j.pecon.2021.06.005

Ramin, M., Labencki, T., Boyd, D., Trolle, D., \& Arhonditsis, G. B. (2012). A Bayesian synthesis of predictions from different models for setting water quality criteria. Ecological Modelling, 242, 127-145. 10.1016/j.ecolmodel.2012.05.0

Salman, R., Nikoo, M. R., Shojaeezadeh, S. A., Beiglou, P. H. B., Sadegh, M., Adamowski, J. F., \& Alamdari, N. (2021). A novel Bayesian maximum entropy-based approach for optimal design of water quality monitoring networks in rivers. Journal of Hydrology, 603, 126822. 10.1016/j.jhydrol.2021.126822

Silva, M. O., Olinda, R. A., Mioto, C. L., \& Barbosa, D. S. (2020). Análise plurianual da qualidade das águas de bacia tributária do Pantanal brasileiro. Revista Ibero Americana de Ciências Ambientais, 11(2), 172-181. 10.6008/CBPC2179-6858.2020.002.0019

Sha, J., Li, Z., Swaney, D. P., Hong, B., Wang, W., \& Wang, Y. (2014). Application of a Bayesian Watershed Model Linking Multivariate Statistical Analysis to Support Watershed-Scale Nitrogen Management in China. Water Resources Management, 28(11), 3681-3695. 10.1007/s11269-014-0696-X

Souza, A. V. V., \& Loverde-Oliveira, S. M. (2014). Analysis of the water quality of the Rio Vermelho in Mato Grosso: during the flood season in 2014. Biodiversity, 13(2), 115-126.

Wan, R., Cai, S., Li, H., Yang, G., Li, Z., \& Nie, X. (2014). Inferring land use and land cover impact on stream water quality using a Bayesian hierarchical modeling approach in the Xitiaoxi River Watershed, China. Journal of Environmental Management, 133, 1-11. 10.1016/j.jenvman.2013.11.035

Wijesiri, B., Deilami, K., McGree, J., \& Goonetilleke, A. (2018). Use of surrogate indicators for the evaluation of potential health risks due to poor urban water quality: A Bayesian Network approach. Environmental Pollution, 233, 655-661. 10.1016/j.envpol.2017.10.076

Zhang, M., Zhi, Y., Shi, J., \& Wu, L. (2018). Apportionment and uncertainty analysis of nitrate sources based on the dual isotope approach and a Bayesian isotope mixing model at the watershed scale. Science of The Total Environment, 639, 1175-1187. 10.1016/j.scitotenv.2018.05.2 